\title{
PENGARUH KOMPENSASI FINANSIAL DAN NON FINANSIAL TERHADAP KINERJA KARYAWAN BUMN \\ ( Studi Kasus PT. Bank Rakyat Indonesia (Persero) Tbk. Cabang Teluk Kuantan) \\ Larbiel Hadi \\ (Dosen Fakultas Ekonomi dan Ilmu Sosial UIN Suska Riau)
}

\begin{abstract}
This study aims to determine the effect of financial compensation to the performance of employees of PT. Bank Rakyat Indonesia (Persero) Tbk. Cabang Teluk Kuantan, the influence of non-financial compensation to the performance of employees of PT. Bank Rakyat Indonesia (Persero) Tbk. Cabang Teluk Kuantan, the influence of financial and nonfinancial compensation simultaneously to the performance of employees of PT. Bank Rakyat Indonesia (Persero) Tbk. Cabang Teluk Kuantan and whether the performance difference between regular employees and contract employees of PT. Bank Rakyat Indonesia (Persero) Tbk. Cabang Teluk Kuantan. The sample in this study amounted to 44 respondents were distributed to the employees of PT. Bank Rakyat Indonesia (Persero) Tbk. Cabang Teluk Kuantan. Data analysis methods used are quantitative analyzes using the validity test, reliability test, test for normality, the assumption of classical test, multiple linear regression analysis and mean difference test. The results of studies using multiple linear regression analysis is financial compensation and a significant positive effect on the performance of employees of PT. Bank Rakyat Indonesia (Persero) Tbk. Cabang Teluk Kuantan, non financial compensation and a significant positive effect on the performance of employees of PT. Bank Rakyat Indonesia (Persero) Tbk. Cabang Teluk Kuantan, financial and nonfinancial compensation simultaneously positive and significant effect on the performance of employees of PT. Bank Rakyat Indonesia (Persero) Tbk. Cabang Teluk Kuantan, while the test results by using the average difference is there is no performance difference between regular employees and contract employees of PT. Bank Rakyat Indonesia (Persero) Tbk. Cabang Teluk Kuantan.
\end{abstract}

Keywords: Financial Compensation, Nonfinancial Compensation, Employee Performance, Permanent Employees, Contract Employees

\section{PENDAHULUAN}

Dalam era persaingan global, keberadaan sumber daya manusia yang handal memiliki peran yang lebih strategis dibandingkan sumber daya yang lain. Sumber daya manusia adalah harta yang paling penting yang dimiliki oleh suatu organisasi, sedangkan manajemen yang efektif adalah kunci bagi keberhasilan suatu organisasi tersebut. Sadar akan pentingnya sumber daya manusia bagi kelangsungan hidup dan kemajuan suatu perusahaan, maka suatu perusahaan harus memberikan perhatian khusus pada faktor produksi ini dan sudah sewajarnya pemilik perusahaan memandang sumber daya manusia lebih dari sekedar aset 
perusahaan dan menjadikan mitra dalam berusaha.

Perusahaan harus dapat bersikap adil atas apa yang telah diberikan oleh sumber daya manusia kepada perusahaan, karena setiap karyawan berhak mendapatkan penghargaan dan perlakuan yang adil dari pimpinannya sebagai timbal balik atas jasa yang diberikannya, sehingga dapat mendorong para karyawan untuk lebih termotivasi dalam menjalankan kewajibannya sebagai seorang pekerja. Hubungan kerja yang saling menguntungkan antara perusahaan dan karyawan sangat diperlukan dalam rangka mendorong semangat kerja karyawan. Karyawan memberikan prestasi kerja yang baik untuk kemajuan perusahaan, sedangkan perusahaan memberikan kompensasi yang sesuai atas prestasi kerja yang telah diberikan karyawan terhadap perusahaan.

Panggabean

(2004:76)

menggolongkan kompensasi ke dalam dua kelompok, yaitu Pemberian kompensasi dapat diberikan dalam berbagai bentuk, baik itu finansial maupun nonfinansial. Kompensasi finansial ada yang langsung dan ada yang tidak langsung. Kompensasi finansial langsung terdiri atas gaji/upah dan insentif (komisi dan bonus). Sedangkan kompensasi finansial tidak langsung dapat berupa berbagai macam fasilitas dan tunjangan. Kompensasi nonfinansial terdiri atas pekerjaan dan lingkungan kerja, seperti tugas-tugas yang menarik, tantangan baru yang menarik, pengakuan, rasa pencapaian, kerabat kerja yang menyenangkan, lingkungan kerja yang nyaman dan sebagainya. Pemberian kompensasi sangat penting bagi karyawan, karena besar kecilnya kompensasi merupakan ukuran terhadap prestasi kerja karyawan.
Penelitian ini mengambil populasi beberapa karyawan PT. Bank Rakyat Indonesia (Persero) Tbk. Cabang Teluk Kuantan. Penelitian ini dilakukan dengan metode survei, yaitu mengambil data dengan memberikan kuesioner kepada beberapa karyawan PT. Bank Rakyat Indonesia (Persero) Tbk. Cabang Teluk Kuantan. Berdasarkan latar belakang yang dikemukakan di atas maka penulis mengambil judul "Pengaruh Kompensasi Finansial dan Nonfinansial terhadap Kinerja Karyawan PT. Bank Rakyat Indonesia (Persero) Tbk. Cabang Teluk Kuantan".

\section{Rumusan Masalah}

Berdasarkan latar belakang yang dikemukakan di atas maka rumusan masalahnya adalah sebagai berikut :

1. Apakah kompensasi finansial berpengaruh secara positif dan signifikan terhadap kinerja karyawan?

2. Apakah kompensasi nonfinansial berpengaruh secara positif dan signifikan terhadap kinerja karyawan?

3. Apakah kompensasi finansial dan nonfinansial berpengaruh secara simultan terhadap kinerja karyawan ?

4. Apakah terdapat perbedaan kinerja antara karyawan tetap dan karyawan kontrak?

\section{LANDASAN TEORI}

\section{Pengertian Manajemen}

Menurut R.W. Grifin dalam Puspopranoto (2006, p. 99) Manajemen adalah serangkaian aktivitas (termasuk perencanaan, dan pengambilan keputusan, pengorganisasian, kepemimpinan dan pengendalian) yang diarahkan Pada sumber-sumber daya oganisasi (manusia, 
financial, fisik, dan informasi) dengan maksud untuk mencapai tujuan organisasi, secara efisien dan efektif". Kesimpulan bahwa manajemen merupakan serangkaian aktifitas yang dilakukan oleh sebuah organisasi atau perusahan yang bertujuan untuk mencapai tujuan organisasi yang efisien dan efektif.

\section{Pengertian Manajemen Sumber Daya Ma nusia}

Menurut Drs, Melayu S.P Hasibuan (2008, p. 10) manajemen sumber daya manusia adalah ilmu dan seni mengatur hubungan dan peranan tenaga kerja agar lebih efektif dan efisien membantu terwujudnya tujuan perusahaan, karyawan dan masyarakat.

Menurut Henry Simamora (2006, p. 5) manajemen sumber daya manusia adalah ilmu yang menyangkut desain dan implementasi sistem perencanaan, penyusunan karyawan, pengembangan karyawan, pengelolaan karier, evaluasi kinerja, kompensasi karyawan dan hubungan ketenagakerjaan yang baik. Manajemen sumber daya manusia melibatkan semua keputusan dan praktek manajemen yang mempengaruhi secara lansung sumber daya manusianya"

Menurut Hadari Nawawi (2006, p. 42) manajemen sumber daya manusia adalah pengelolaan individu yang bekerja dalam organisasi berupa hubugan antara pekerja dan pekerjaan (employeremployee), terutama untuk menciptakan pemanfaatan individu-individu secara produktif sebagai usaha mencapai tujuan organisasi dan dalam rangka perwujudan kepuasan kebutuhan individu-individu tersebut.

Dari beberapa teori diatas dapat diambil kesimpulan bahwa manajemen sumber daya merupakan ilmu yang mengatur sumber daya manusia dan mengolah sumber daya manusia yang ada sehingga menjadi sumber daya manusia yang berkualitas, manajamen sumber daya sangat kuat dengan motto "the right man on the right place" yang artinya seseorang ditempatkan sesuai dengan kemampuan dan keahlian di bidangnya.

\section{Pengertian Kompensasi}

Kompensasi yaitu imbalan berupa uang atau bukan uang yang diberikan kepada karyawan dalam perusahaan atau organisasi. Sastrohadiwiryo (2005:181) mengemukakan bahwa Kompensasi adalah imbalan jasa atau balas jasa yang diberikan oleh perusahaan kepada para tenaga kerja, karena tenaga kerja tersebut telah memberikan sumbangan tenaga dan pikiran demi kemajuan perusahaan guna mencapai tujuan yang telah ditetapkan. Sedangkan Menurut Martoyo (2007:116) kompensasi adalah pengaturan keseluruhan pemberian balas jasa bagi employers maupun employees baik yang langsung berupa uang (finansial) maupun yang tidak langsung berupa uang (nonfinansial).

$$
\text { Hasibuan }
$$

menyatakan bahwa kompensasi adalah semua pendapatan yang berbentuk uang, barang langsung atau tidak langsung yang diterima karyawan sebagai imbalan atas jasa yang diberikan kepada perusahaan. Seberapa besar kompensasi diberikan harus sedemikian rupa sehingga mampu mengikat para karyawan. Hal ini adalah sangat penting sebab bila kompensasi yang diberikan kepada para karyawan terlalu kecil dibandingkan badan usaha lain, maka hal ini dapat menyebabkan karyawan pindah ke badan usaha yang lain. Oleh karena itu, perhatian organisasi terhadap pengaturan kompensasi secara benar dan adil merupakan hal yang sangat penting (Martoyo, 2007:86). 


\section{Jenis-Jenis Kompensasi}

Mulyadi

(2001:419-420)

menggolongkan penghargaan ke dalam dua kelompok, yaitu Penghargaan intrinsik berupa rasa puas diri yang diperoleh seseorang yang telah berhasil menyelesikan pekerjaannya dengan baik dan telah mencapai sasaran tertentu, misalnya dengan penambahan tanggung jawab, pengayaan pekerjaan (job enrichment) dan usaha lain yang meningkatkan harga diri sesorang dan yang mendorong orang untuk menjadi yang terbaik. Penghargaan ekstrinsik terdiri dari kompensasi yang diberikan kepada karyawan baik berupa kompensasi finansial seperti gaji, honorarium dan bonus, penghargaan tidak langsung seperti asuransi kecelakaan, honorarium liburan dan tunjangan masa sakit serta penghargaan nonkeuangan berupa ruang kerja yang memiliki lokasi istimewa, peralatan kantor yang istimewa, tempat parkir khusus, gelar istimewa dan sekretaris pribadi.

Mondy et al., (1993:442-443) mengemukakan bahwa bentuk dari kompensasi yang diberikan perusahaan kepada karyawan dapat dikelompokkan menjadi 2 (dua), yaitu:

1. Financial Compensation

a. Direct Financial Compensation

Direct financial compensation consists of the pay that a person receives in the form of wages, salaries, bonuses, and commissions.

b. Indirect Financial Compensation

Indirect financial compensation (benefits) includes all financial rewards that are not included in direct compensation. This form of compensation includes a wide variety of rewards that are normally received indirectly by the employee. This form of compensation includes: 1.Insurance plans : life, health, surgical, dental, casualty, etc.
2. Social assistance benefits : retirement plans, social security, workers' compensation, educational assistance, employee services.

3.Paid absences : vacations, holidays, sick leave, etc.

2. Nonfinancial Compensation Nonfinancial compensation consists of the satisfaction that a person receives from the job itself or from the psychological and/or physical environment in which the person works. This type of nonfinancial compensation consists of the satisfaction received from performing meaningful job-related tasks. This form of nonfinancial compensation involves the psychological and/or physical environment in which the person works. This form of compensation includes :

a. The Job : interesting duties, challenge, responsibility, opportunity for recognition, feeling of achievement, advancement opportunities.

b. Job environment : sound policies, competent supervision, congenial coworkers, appropriate status symbols, comfortable working conditions, flextime, compressed workweek, job sharing, cafeteria compensation, telecommuting.

Nawawi (2005:316-317) secara garis besar membagi kompensasi menjadi tiga jenis, yaitu :

1. Kompensasi Langsung

Penghargaan/ganjaran yang disebut gaji atau upah, yang dibayar secara tetap berdasarkan tenggang waktu yang tetap.

2. Kompensasi Tidak Langsung Pemberian bagian keuntungan/manfaat bagi para pekerja di luar gaji atau upah tetap, 
dapat berupa uang atau barang.

3. Insentif

Penghargaan atau ganjaran yang diberikan untuk memotivasi para pekerja agar produktivitas kerjanya tinggi, sifatnya tidak tetap atau sewaktu-waktu.

Berdasarkan berbagai pendapat para ahli tersebut, dapat disimpulkan bahwa secara umum kompensasi dapat dibagi menjadi dua kelompok besar, yaitu berdasarkan bentuk kompensasi dan cara pemberiannya.

Syaifullah (2005:9) membagi kompensasi menjadi dua kelompok besar, yaitu: Kompensasi berdasarkan bentuknya, terdiri atas kompensasi finansial dan kompensasi nonfinansial. Kompensasi berdasarkan cara pemberiannya, terdiri atas kompensasi langsung dan kompensasi tidak langsung. Kompensasi finansial langsung terdiri atas bayaran (pay) yang diperoleh seseorang dalam bentuk gaji, upah, bonus, atau komisi.

Sedangkan kompensasi finansial tidak langsung yang merupakan tunjangan, meliputi semua imbalan finansial yang tidak mencakup dalam kompensasi finansial langsung seperti program asuransi tenaga kerja (jamsostek), pertolongan sosial, pembayaran biaya sakit (berobat), cuti dan lain-lain. Kompensasi nonfinansial merupakan imbalan dalam bentuk kepuasan seseorang yang diperoleh dari pekerjaan itu sendiri, atau dari lingkungan baik secara fisik atau psikologis dimana orang tersebut bekerja. Ciri dari kompensasi nonfinansial ini meliputi kepuasan yang didapat dari pelaksanaan tugas- tugas yang bermakna yang berhubungan dengan pekerjaan.

\section{Fungsi dan Tujuan Pemberian Kompenssi}

\begin{abstract}
Hasibuan
(2008:120)

mengemukakan bahwa program kompensasi atau balas jasa umumnya bertujuan untuk kepentingan perusahaan, karyawan dan pemerintah/masyarakat. Supaya tercapai dan memberikan kepuasan bagi semua pihak hendaknya program kompensasi berdasarkan prinsip adil dan wajar, undang-undang perburuhan serta memperhatikan konsistensi internal dan eksternal. Fungsi pemberian kompensasi menurut Samsuddin
\end{abstract} (2006:188) adalah sebagai berikut :

1. Pengalokasian sumber daya manusia secara efisien. Fungsi ini menunjukkan pemberian kompensasi pada karyawan yang berprestasi akan mendorong mereka untuk bekerja dengan lebih baik.

2. Penggunaan sumber daya manusia secara lebih efisien dan efektif. Dengan pemberian kompensasi kepada karyawan mengandung implikasi bahwa organisasi akan menggunakan tenaga karyawan tersebut dengan seefisien dan se efektif mungkin.

3. Mendorong stabilitas dan pertumbuhan ekonomi. Sistem pemberian kompensasi dapat membantu stabilitas organisas dan mendorong pertumbuhan ekonomi negara secara keseluruhan.

Tujuan pemberian kompensasi menurut Hasibuan (2008:121-122) adalah sebagai berikut:

1. Ikatan Kerja Sama. Dengan pemberian kompensasi terjalinlah ikatan kerja sama formal antara majikan dengan karyawan. Karyawan harus mengerjakan tugas-tugasnya dengan baik, sedangkan pengusaha/majikan wajib membayar kompensasi sesuai dengan perjanjian yang 
disepakati.

2. Kepuasan Kerja. Dengan balas jasa, karyawan akan dapat memenuhi kebutuhan-kebutuhan fisik, status sosial dan egoistiknya sehingga memperoleh kepuasan kerja dari jabatannya.

3. Pengadaan Efektif. Jika program kompensasi ditetapkan cukup besar, pengadaan karyawan yang qualified untuk perusahaan akan lebih mudah.

4. Motivasi. Jika balas jasa yang diberikan cukup besar, manajer akan mudah memotivasi bawahannya.

5. Stabilitas Karyawan. Dengan program kompensasi atas prinsip adil dan layak serta eksternal konsistensi yang kompetitif maka stabilitas karyawan lebih terjamin karena turn-over relatif kecil.

6. Disiplin. Pemberian balas jasa yang cukup besar maka disiplin karyawan semakin baik. Mereka akan menyadari dan menaati peraturan-peraturan yang berlaku.

7. Pengaruh Serikat Buruh. Dengan program kompensasi yang baik pengaruh serikat buruh dapat dihindarkan dan karyawan akan berkonsentrasi pada pekerjaannya.

8. Pengaruh Pemerintah. Jika program kompensasi sesuai dengan undang undang perburuhan yang berlaku (seperti batas upah minimum), maka intervensi pemerintah dapat dihindarkan.

Arep dan Tanjung (2003:197) mengemukakan bahwa tujuan membuat manajemen balas jasa (kompensasi) dalam jangka panjang terdiri atas 3 bagian yaitu :

1. Memperoleh karyawan yang berkualitas dengan cara menarik karyawan yang handal ke dalam organisasi. Jika kompensasi yang diberikan tinggi, maka banyak orang yang berminat bekerja di tempat tersebut, sehingga seleksi dapat dilakukan dengan cara yang sangat ketat.

2. Meningkatkan gairah dan semangat kerja melalui memotivasi karyawan untuk mencapai prestasi unggul. Ini akan berhasil jika insentif yang diterapkan sangat menggiurkan bagi para pegawai.

3. Timbulnya long life employment (bekerja seumur hidup atau timbul loyalitas dalam bekerja di tempat tersebut). Secara sederhana dapat disimpulkan bahwa pemberian kompensasi hendaknya memberikan kepuasan kepada karyawan, sehingga dapat diperoleh karyawan yang handal dan berkualitas serta dapat mempertahankan karyawan yang ada saat ini.

\section{Faktorfaktor yang Mempengaruhi Pem berian Kompensasi}

Sistem pemberian kompensasi oleh perusahaan kepada karyawannya dipengaruhi oleh berbagai faktor. Faktor-faktor ini merupakan tantangan setiap organisasi untuk menentukan kebijaksanaan kompensasi untuk karyawannya. Faktor-faktor tersebut menurut Hasibuan (2008:128-129) adalah sebagai berikut :

1. Penawaran dan Permintaan. Jika pencari kerja (penawaran) lebih banyak daripada lowongan perkerjaan (permintaan) maka kompensasi relatif kecil. Sebaliknya jika pencari kerja lebih sedikit daripada lowongan pekerjaan maka kompensasi relatif semakin besar.

2. Kemampuan dan Kesediaan 
Perusahaan. Apabila kemampuan dan kesediaan perusahaan untuk membayar semakin baik, maka tingkat kompensasi akan semakin besar. Tetapi sebaliknya, jika kemampuan dan kesediaan perusahaan untuk membayar kurang, maka tingkat kompensasi relatif kecil.

3. Serikat Buruh/Organisasi Karyawan. Apabila serikat buruhnya kuat dan berpengaruh maka tingkat kompensasi semakin besar. Sebaliknya jika serikat buruh tidak kuat dan kurang berpengaruh maka tingkat kompensasi relatif kecil.

4. Produktivitas Kerja Karyawan. Jika produktivitas kerja karyawan baik dan banyak maka kompensasi akan semakin besar. Sebaliknya kalau produktivitas kerjanya buruk serta sedikit maka kompensasinya kecil.

5. Pemerintah dengan Undang-undang dan Keppres. Pemerintah dengan Undang-undang dan Keppres menetapkan besarnya batas upah/balas jasa minimum. Peraturan pemerintah ini sangat penting supaya pengusaha tidak sewenang-wenang menetapkan besarnya balas jasa bagi karyawan. Pemerintah berkewajiban melindungi masyarakat dari tindakan sewenang-wenang.

6. Biaya Hidup/Living Cost. Apabila biaya hidup di daerah itu tinggi maka tingkat kompensasi/upah semakin besar. Sebaliknya, jika tingkat biaya hidup di daerah itu rendah maka tingkat kompensasi/upah relatif kecil. Seperti tingkat upah di Jakarta lebih besar dari di Bandung, karena tingkat biaya hidup di Jakarta lebih besar daripada di Bandung.

7. Posisi Jabatan Karyawan. Karyawan yang menduduki jabatan lebih tinggi akan menerima gaji/kompensasi lebih besar. Sebaliknya karyawan yang menduduki jabatan yang lebih rendah akan memperoleh gaji/kompensasi yang kecil. Hal ini wajar karena seseorang yang mendapat kewenangan dan tanggung jawab yang besar harus mendapatkan gaji/kompensasi yang lebih besar pula.

8. Pendidikan dan Pengalaman Kerja. Jika pendidikan lebih tinggi dan pengalaman kerja lebih lama maka gaji/balas jasanya akan semakin besar, karena kecakapan serta keterampilannya lebih baik. Sebaliknya, karyawan yang berpendidikan rendah dan pengalaman kerja yang kurang maka tingkat gaji/kompensasinya kecil.

9. Kondisi Perekonomian Nasional. Apabila kondisi perekonomian nasional sedang maju (boom) maka tingkat upah/kompensasi akan semakin besar, karena akan mendekati kondisi full employment. Sebaliknya, jika kondisi perekonomian kurang maju (depresi) maka tingkat upah rendah, karena terdapat banyak penganggur (unemployment).

10. Jenis dan Sifat Pekerjaan. Kalau jenis dan sifat pekerjaan yang sulit dan mempunyai risiko (finansial, keselamatan) yang besar maka tingkat upah/balas jasanya semakin besar karena membutuhkan kecakapan serta ketelitian untuk mengerjakannya. Tetapi jika jenis dan sifat pekerjaannya mudah dan risiko (finansial, kecelakaannya) kecil, tingkat upah/balas jasanya relatif rendah. Misalnya, pekerjaan merakit komputer balas jasanya lebih besar daripada mengerjakan mencetak batu bata.

\section{Pengertian Kinerja Karyawan}

Perusahaan atau lembaga 
merupakan salah satu bentuk sistem yang terdiri dari beberapa subsistem yang berkaitan satu sama lainnya dalam mencapai tujuan atau sasaran yang diinginkan. Menuntut adanya kinerja yang baik dari setiap individu sebagai bagian dari sistem, dalam hal ini sebenarnya terdapat hubungan yang erat antara kinerja perorangan (individual performance) dengan kinerja lembaga (institusional performance). Apabila kinerja perorangan/karyawan baik, maka kemungkinan besar kinerja perusahaan/lembaga juga baik. Menurut Mangkunegara (2004:67) "kinerja karyawan adalah hasil kerja secara kualitas dan kuantitas yang dicapai oleh seorang karyawan dalam melaksanakan tugasnya sesuai dengan tanggung jawab yang diberikan kepadanya.

\section{Penilaian dan Pengukuran Kinerja}

Penilaian kinerja karyawan adalah suatu proses penilaian kinerja karyawan yang dilakukan pemimpin perusahaan secara sistematik berdasarkan pekerjaan yang ditugaskan kepadanya (Mangkunegara, 2004:69). Menurut Hasibuan (2008:87) penilaian prestasi kerja/kinerja karyawan adalah menilai rasio hasil kerja nyata dengan standar kualitas maupun kuantitas yang dihasilkan setiap karyawan. Tujuan penilaian kinerja yang dikemukakan oleh Sunyoto (1991:1) adalah sebagai berikut:

1. Meningkatkan saling pengertian antara karyawan tentang persyaratan kinerja.

2. Mencatat dan mengakui hasil kerja seorang karyawan, sehingga mereka termotivasi untuk berbuat yang lebih baik, atau sekurang-kurangnya berprestasi sama dengan prestasi terdahulu.

3. Memberikan peluang kepada karyawan untuk mendiskusikan keinginan dan aspirasinya serta meningkatkan kepedulian terhadap karir atau terhadap pekerjaan yang diembannya sekarang.

4. Mendefinisikan atau merumuskan kembali sasaran masa depan, sehingga karyawan termotivasi untuk berprestasi sesuai dengan potensinya.

5. Memeriksa rencana pelaksanaan dan pengembangan yang sesuai dengan kebutuhan pelatihan, khusus rencana diklat dan kemudian menyetujui rencana itu jika ada hal-hal yang perlu diubah.

Manfaat penilaian kinerja karyawan itu sendiri menurut Mulyadi (2004:416) adalah :

1. Mengelola operasi organisasi secara efektif dan efisien melalui pemotivasian karyawan secara maksimum.

2. Membantu pengambilan keputusan yang bersangkutan dengan karyawan, seperti promosi, transfer dan pemberhentian.

3. Mengidentifikasi kebutuhan pelatihan dan pengembangan karyawan dan untuk menyediakan kriteria seleksi dan evaluasi program pelatihan karyawan.

4. Menyediakan umpan balik bagi karyawan mengenai bagaimana atasan mereka menilai kinerja mereka.

5. Menyediakan suatu dasar bagi distribusi penghargaan.

Berdasarkan uraian tentang penilaian kinerja di atas, maka dapat disimpulkan bahwa penilaian kinerja terhadap anggota organisasi atau perusahaan haruslah dilaksanakan secara obyektif, sehingga manfaatnya dapat dirasakan oleh organisasi yang bersangkutan.

Unsur-Unsur Penilaian Kinerja

Sastrohadiwiryo (2005:235-236) 
menjelaskan bahwa pada umumnya unsur-unsur yang perlu diadakan dalam proses penilaian kinerja adalah sebagai berikut :

1. Kesetiaan. Kesetiaan yang dimaksudkan adalah tekad dan kesanggupan menaati, melaksanakan dan mengamalkan sesuatu yang ditaati dengan penuh kesadaran dan tanggung jawab.

2. Prestasi kerja. Yang dimaksud dengan prestasi kerja adalah kinerja yang dicapai oleh seorang tenaga kerja dalam melaksanakan tugas dan pekerjaan yang diberikan kepadanya.

3. Tanggung jawab. Tanggung jawab adalah kesanggupan seorang tenaga kerja dalam menyelesaikan tugas dan pekerjaan yang diserahkan kepadanya dengan sebaik-baiknya dan tepat waktu serta berani memikul risiko atau keputusan yang telah diambilnya atau tindakan yang dilakukannya.

4. Ketaatan. Yang dimaksud dengan ketaatan adalah kesanggupan seorang tenaga kerja untuk menaati segala ketetapan, peraturan perundangundangan dan peraturan perdinasan yang berlaku, menaati perintah perdinasan yang diberikan atasan yang berwenang serta kesanggupan untuk tidak melanggar larangan yang telah ditetapkan perusahaan maupun pemerintah, baik secara tertulis maupun tidak tertulis.

5. Kejujuran. Yang dimaksud dengan kejujuran adalah ketulusan hati seorang tenaga kerja dalam melaksanakan tugas dan pekerjaan serta kemampuan untuk tidak menyalahgunakan wewenang yang telah diberikan kepadanya.

6. Kerja sama. Kerja sama adalah kemampuan seorang tenaga kerja untuk bekerja bersama-sama dengan orang lain dalam menyelesaikan suatu tugas dan pekerjaan yang telah ditetapkan, sehingga mencapai daya guna dan hasil guna yang sebesarbesarnya.

7. Prakarsa. Prakarsa adalah kemampuan seorang tenaga kerja untuk mengambil keputusan, langkah-langkah atau melaksanakan sesuatu tindakan yang diperlukan dalam melaksanakan tugas pokok tanpa menuggu perintah bimbingan dari manajemen lininya.

8. Kepemimpinan. Yang dimaksud dengan kepemimpinan adalah kemampuan yang dimiliki seorang tenaga kerja untuk meyakinkan orang lain (tenaga kerja lain) sehingga dapat dikerahkan secara maksimum untuk melaksanakan tugas pokok.

Ada tiga jenis kriteria-kriteria dalam penilaian prestasi kerja, menurut Syamsuddin dan Yunus (2003:16) dalam Rahayu (2008) yaitu :

1. Kriteria berdasarkan sifat

a. Kemampuan (ability). kapasitas seorang individu untuk mengerjakan berbagai tugas dalam suatu pekerjaan.

b. Loyalitas (loyality). Loyalitas adalah suatu bentuk sikap yang senantiasa melihat segala sesuatunya sebagai proses perbaikan demi perbaikan.

c. Kejujuran (honesty) atau transparansi. Kejujuran (honesty) adalah suatu bentuk keterusterangan atau bentuk keterbukaan dalam melaksanakan suatu pekerjaan.

d. Kreativitas (creativity). Kreatifitas adalah kemampuan memproduksi cerita atau ide-ide baru yang dapat digunakan untuk membantu proses penyelesaian pekerjaan.

e. Kemampuan memimpin (leadership). Kepemimpinan 
(leadership) adalah kemampuan mempengaruhi, memotivasi dan mengarahkan orang lain untuk mencapai tujuan-tujuan yang diinginkan.

2. Kriteria berdasarkan perilaku:

a. Melaksanakan tugas (perform task). Hal ini berkaitan dengan tingkat pelaksanaan tugas.

b. Mengikuti instruksi (obey instruction). Hal ini berkaitan dengan bagaimana seseorang mengikuti instruksi dalam melaksanakan tugasnya.

c. Melaporkan permasalahan (report problem). Hal ini meyangkut apakah seseorang melaporkan permasalahan yang dihadapinya dalam melaksanakan tugas.

d. Memelihara peralatan (maintain equipment). Dimaksudkan pada tingkat pemeliharaan peralatan dalam melaksanakan proses penyelesaian pekerjaan.

e. Memelihara adminstrasi (maintain records). Dimaksudkan pada tingkat pemeliharaan administrasi dalam melaksanakan proses penyelesaian pekerjaan.

f. Mengikuti aturan-aturan (follow rules). Dimaksudkan pada sejauh mana aturan-aturan yang telah ditetapkan dapat diikuti dalamproses penyelesaian pekerjaan.

g. Mengajukan usul atau saran (submit suggestions). Dimaksudkan pada tingkat pemberian usul dan saran pada saat melaksanakan tugas atau pekerjaan.

3. Kriteria berdasarkan hasil :

a. Hasil yang dicapai sesuai dengan perencanaan. Dimaksudkan pada tingkat hasil yang dicapai pada masing-masing karyawan (production level). b. Kualitas pekerjaan. Dimaksudkan pada tingkat kualitas dari hasil pekerjaan yang telah dilaksanakan (quality production).

c. Pekerjaan yang tersisa. Dimaksudkan pada tingkat penyelesaian pekerjaan yang tersisa (scrap).

d. Memperbaiki peralatan (equipment repairs). Dimaksudkan bagaimana peralatan yang telah digunakan dapat diperbaiki 2.6 Hubungan antara Kompensasi Finansial dan Nonfinansial terhadap Kinerja Karyawan Hasibuan (2008:117) mengemukakan bahwa : Besarnya balas jasa ditentukan dan diketahui sebelumnya, sehingga karyawan secara pasti mengetahui besarnya balas jasa/kompensasi yang akan diterimanya. Kompensasi inilah yang akan dipergunakan karyawan itu beserta keluarganya untuk memenuhi kebutuhankebutuhannya.

Besarnya kompensasi yang diterima karyawan mencerminkan status, pengakuan dan tingkat pemenuhan kebutuhan yang dinikmati oleh karyawan bersama keluarganya. Jika balas jasa yang diterima karyawan semakin besar, berarti jabatannya semakin tinggi, statusnya semakin baik, dan pemenuhan kebutuhan yang dinikmatinya semakin banyak pula. Dengan demikian kepuasan kerjanya juga semakin baik. Disinilah letak pentingnya kompensasi bagi karyawan sebagai seorang penjual tenaga (fisik dan pikiran). Apabila kompensasi yang diterima karyawan (kompensasi finansial dan nonfinansial) semakin besar maka kinerja karyawan semakin tinggi, sebaliknya apabila kompensasi yang diterima karyawan (kompensasi 
finansial dan nonfinansial) semakin rendah, maka kinerja karyawan juga rendah.

\section{Kinerja Karyawan Tetap dan Karyawan Kontrak}

Karyawan tetap adalah karyawan yang dipekerjakan oleh perusahaan dan tak ada batasan jangka waktu lamanya bekerja. Karyawan kontrak adalah karyawan yang dipekerjakan oleh perusahaan untuk jangka waktu tertentu saja, waktunya terbatas maksimal hanya 3 tahun. Hubungan kerja antara perusahaan dan karyawan tetap dituangkan dalam Perjanjian Kerja untuk Waktu Tidak Tertentu/PKWTT, sedangkan hubungan kerja antara perusahaan dan karyawan kontrak dituangkan dalam Perjanjian Kerja untuk waktu tertentu PKWTT. (http://andresitohang.wordpress.com/ab out/perbedaankaryawankontrakoutsourc ingdengankaryawantetap/).

Karyawan tetap yang bekerja dalam sebuah perusahaan cenderung lebih merasa aman, sebab kepastian masa depan sangat ditentukan oleh sikap positif yang ditunjukkan selama bekerja dan tidak dibebani oleh waktu atau masa kontrak. Salah satu faktor yang akan membuat mereka termotivasi dalam bekerja adalah pencapaian jenjang karier atau jabatan dalam perusahaan tersebu. Namun sebaliknya, jika sikap positif yang ditunjukkan karyawan tetap dalam bekerja sangat minim, maka motivasi berprestasi karyawan tetap tersebut menjadi sangat rendah dan tentunya kinerja karyawan tersebut menjadi sangat rendah. Adanya rasa aman menjadi karyawan tetap, tidak jarang menjadikan karyawan yang bersangkutan terlena dan tidak terpacu dengan target-target perusahaan. Kondisi ini menciptakan situasi tidak produktif dalam diri karyawan dan tentunya akan sangat berpengaruh terhadap pencapaian target dan produktivitas perusahaan.

Lain halnya pada karyawan kontrak, mengingat berkecamuknya perasaan dan pikiran penuh ketidakpastian yang terus datang, maka implikasi psikologis terhadap kinerja karyawan kontrak akan nampak pada motivasi karyawan tersebut. Namun demikian ketidakpastian masa depan juga bisa menambah semangat kerja atau motivasi kerja karyawan kontrak untuk semakin produktif dan mendapatkan penilaian lebih dari perusahaan. Hal ini karena produktivitas dan kinerja karyawan kontrak merupakan penilaian utama diperpanjangnya masa kontrak mereka oleh perusahaan atau bahkan diangkat menjadi karyawan tetap. Karyawan kontrak tidak menginginkan prestasi kerjanya dinilai rendah oleh perusahaan, sehingga berakibat terjadi pemutusan kontrak oleh pihak bank atau perusahaan. Adanya situasi seperti ini membuat penggunaan karyawan kontrak menjadi alternatif yang disukai oleh pihak bank, karena mendapatkan prestasi kerja yang tinggi dari karyawan.

\section{Penelitian Terdahulu}

Dalam penelitian sebelumnya, Allo (2009) meneliti analisis kompensasi dan pengaruhnya terhadap kinerja petugas P3KB pada Dinas Kehutanan Propinsi Riau. Hasil penelitian tersebut diperoleh kesimpulan bahwa kompensasi finansial langsung mempunyai hubungan korelasi positif tinggi yang paling dominan terhadap kinerja petugas $\mathrm{P} 3 \mathrm{~KB}$ pada Dinas Kehutanan Propinsi Riau dibandingkan kompensasi finansial tidak langsung dan kompensasi 
nonfinansial.

$$
\text { Rahayu (2008) meneliti }
$$
pengaruh sistem penghargaan terhadap kinerja pegawai pada Perum Bulog Divisi Regional Palu. Sistem penghargaan dalam penelitian ini terdiri dari kompensasi finansial dan kompensasi nonfinansial. Kompensasi finansial terdiri dari gaji, bonus dan tunjangan berpengaruh signifikan terhadap kinerja pegawai. Demikian juga dengan kompensasi nonfinansial yakni pekerjaan dan lingkungan berpengaruh signifikan terhadap kinerja pegawai.

Dalam penelitian ini populasi yang digunakan adalah beberapa karyawan yang bekerja pada PT. Bank Rakyat Indonesia (Persero) Tbk. Cabang Teluk Kuantan yang berlokasi di Jalan Achmad Yani No.8 Teluk Kuantan baik karyawan tetap maupun karyawan kontrak. Penentuan sampel dalam penelitian ini, menggunakan metode proportionate stratified random sampling dengan tingkat ketelitian sebesar 10\%. Metode proportionate stratified random sampling ini adalah pengambilan sampel dari anggota populasi secara acak dan berstrata secara proporsional.

Berdasarkan tujuan dari penelitian ini, maka beberapa metode analisis data yang akan digunakan dalam penelitian ini adalah sebagai berikut:

\section{Uji Instrumen Penelitian}

a. Uji Validitas atau Kesahihan

Pengujian validitas data dalam penelitian ini menggunakan metode korelasi Bivariate Pearson (Korelasi Pearson Product Moment). Priyatno (2010:90) mengemukakan bahwa Analisis ini dilakukan dengan cara mengkorelasikan masing-masing skor item dengan skor total.

b. Uji Reliabilitas atau Keandalan

Dalam penelitian ini uji

reliabilitas dilakukan dengan

metode Cronbach's Alpha.

\section{Uji Normalitas}

Uji normalitas data digunakan untuk mengetahui apakah populasi data berdistribusi normal atau tidak. Deteksi normal dilakukan dengan penyebaran data (titik) pada sumbu diagonal dari grafik.

Dasar pengambilan keputusan :

1. Jika data menyebar di sekitar garis diagonal dan mengikuti arah garis diagonal, maka model regresi memenuhi asumsi normalitas.

2. Jika data menyebar jauh dari garis diagonal dan tidak mengikuti arah garis diagonal, maka model regresi tidak memenuhi asumsi normalitas.

\section{Uji Asumsi Klasik}

Langkah ketiga adalah uji asumsi klasik, dimana pengujian ini digunakan untuk memperoleh hasil/nilai yang tidak bias atau estimator linear tidak bias yang terbaik (Best Linear Unbiased Estimator/BLUE). Asumsi klasik tersebut yaitu:

a. Multikolinearitas

Uji multikolinearitas dalam penelitian ini adalah dengan melihat nilai Inflation Factor (VIF) pada model regresi.

b. Heteroskedastisitas

Uji heteroskedastisitas digunakan untuk mengetahui ada atau tidaknya ketidaksamaan varian dari residual pada model regresi. Prasyarat yang harus dipenuhi dalam model regresi adalah tidak adanya gejala heteroskedastisitas.

\section{Uji Hipotesis}

\begin{tabular}{llr}
\multicolumn{2}{c}{ Langkah $\begin{array}{c}\text { terakhir } \\
\text { pengujian }\end{array}$ hipotesis } & dengan \\
menggunakan & analisis linier & regresi \\
berganda dan & uji perbedaan rata-rata
\end{tabular}


(Independent Samples T Test). Untuk hipotesis pertama, kedua dan ketiga, digunakan analisis regresiinier berganda. Analisis ini untuk memprediksikan nilai dari variabel dependen apabila nilai variabel independen mengalami kenaikan atau penurunan dan untuk mengetahui arah hubungan antara variabel independen dengan variabel dependen apakah masing-masing variabel independen berhubungan positif atau negatif. Dalam penelitian ini, variabel dependen adalah kinerja karyawan, sementara untuk variabel independen, peneliti menggunakan variabel kompensasi finansial dan kompensasi nonfinansial. Jika dimasukkan pada formulasi regresi linier berganda, maka akan diperoleh persamaan regresi linier berganda sebagai berikut :

$\mathrm{Y}=\mathrm{a}+\mathrm{b} 1 \mathrm{X} 1+\mathrm{b} 2 \mathrm{X} 2+\mathrm{e}$

Keterangan :

$\begin{array}{lll}\mathrm{Y} & = & \text { Kinerja Karyawan } \\ \mathrm{a} & = & \text { Konstanta } \\ \mathrm{X} 1 & = & \text { Kompensasi Finansial } \\ \mathrm{X} 2 & = & \text { Kompensasi }\end{array}$

Nonfinansial

b1, b2 $=\quad$ Koefisien Regresi

$\mathrm{e}=$ Faktor Pengganggu

Untuk menguji hipotesis

keempat, digunakan uji perbedaan ratarata (Independent Samples $\mathrm{T}$ Test). Priyatno (2010:32) mengemukakan bahwa "uji ini digunakan untuk mengetahui ada atau tidaknya perbedaan rata-rata antara dua kelompok sampel yang tidak berhubungan". Dalam penelitian ini, dua kelompok sampel tersebut adalah kelompok karyawan tetap dan karyawan kontrak. Ada dua tahapan analisis, yaitu:

a. Tahapan pertama analisis, yaitu uji kesamaan varian (homogenitas) dengan F test (Levene's Test), diuji apakah varians populasi kedua sampel tersebut sama atau berbeda. b. Tahapan kedua, yaitu uji T Test dan berdasarkan hasil analisis pada bagian a, diambil suatu keputusan.

Kriteria pengambilan keputusan adalah sebagai berikut :

a. Jika probabilitas dengan nilai sig < 0,05 maka dapat disimpulkan bahwa terdapat perbedaan yang signifikan antara kelompok yang dianalisis. Dengan demikian, terdapat perbedaan yang signifikan antara karyawan tetap dengan karyawan kontrak PT. Bank Rakyat Indonesia (Persero) Tbk. Cabang Teluk Kuantan.

b. Jika probabilitas dengan sig >0,05 maka dapat disimpulkan bahwa tidak terdapat perbedaan yang signifikan antara kelompok yang dianalisis. Dengan demikian, tidak terdapat perbedaan kinerja yang signifikan antara karyawan tetap dan karyawan kontrak PT. Bank Rakyat Indonesia (Persero) Tbk.Cabang Teluk Kuantan.

\section{HASIL DAN PEMBAHASAN}

\section{Pengumpulan Data}

Populasi seluruh karyawan pada PT. Bank Rakyat Indonesia (Persero) Tbk. Cabang Teluk Kuantan yang berlokasi di Jalan Achmad Yani No.8 Teluk Kuantan berjumlah 127 orang, baik karyawan tetap maupun karyawan kontrak. Menurut data yang diperoleh dari PT. Bank Rakyat Indonesia (Persero) Tbk. Cabang Teluk Kuantan saat ini terdapat 127 karyawan dengan rincian sebagai berikut :

a. Karyawan tetap : 91 orang karyawan

b. Karyawan kontrak : 36 orang karyawan

Penentuan sampel dalam penelitian ini menggunakan metode proportionate random sampling dengan tingkat ketelitian sebesar 10\%. Metode 
proportionate random sampling ini adalah pengambilan sampel dari anggota populasi secara acak dan berstrata secara proporsional. Langkahlangkah penentuan sampel sebagai berikut :

a. Menentukan jumlah sampel dari populasi dengan tingkat ketelitian $10 \%$. Dari rumus Slovin diperoleh jumlah sampel sebesar 56 responden (karyawan)

b. Menentukan sampel berstrata dengan rumus :

$\mathrm{ni}=(\mathrm{Ni}: \mathrm{N}) \cdot \mathrm{n}($ Sugiyono 1999:67

dalam Riduwan 2011:66)

Karyawan tetap $=91: 127 \times 56=$ $40,12 \approx 40$ karyawan

Karyawan kontrak $=36: 127 \times 56=$ $15,87 \approx 16$ karyawan

\section{Analisis Deskriptif Variabel Penelitian}

Hasil uji statistik deskriptif akan diuraikan pada bagian ini. Variabel independen yaitu kompensasi finansial (X1) yang terdiri dari 12 item pernyataan dan kompensasi nonfinansial (X2) juga terdiri dari 12 item pernyataan, sedangkan variabel dependen yaitu kinerja karyawan (Y) terbagi atas 3 dimensi dengan 30 pernyataan. Untuk lebih jelasnya, berikut ini akan diuraikan tentang deskripsi variabel penelitian.

\section{Kompensasi Finansial (X1)}

Variabel kompensasi finansial terdiri dari tiga dimensi, yaitu gaji, bonus dan program-program proteksi. Dimensi gaji terdiri dari 3 item pernyataan Dimensi bonus terdiri dari 3 item pernyataan. Dimensi program-program proteksi dengan indikator asuransi kesehatan, asuransi keselamatan kerja dan tunjangan pensiun (pesangon) terdiri dari 6 item pernyataan, dengan demikian ada 12 item pernyataan untuk variabel kompensasi finansial (X1).

Tabel

Statistik Deskriptif Variabel Kompensasi Finansial

\begin{tabular}{|l|r|r|}
\hline \multicolumn{1}{|c|}{ Skala } & Frekuensi & \multicolumn{2}{c|}{ Persentase } \\
\hline 1 = Sangat Tidak Setuju & 10 & $1,9 \%$ \\
2 = Tidak Setuju & 15 & $2,84 \%$ \\
3 = Ragu-ragu & 43 & $8,14 \%$ \\
4 = Setuju & 347 & $65,72 \%$ \\
5 = Sangat Setuju & 113 & $21,40 \%$ \\
\hline Total & 528 & $100 \%$ \\
\hline Rata-rata =4,05 & \multicolumn{2}{|}{} \\
Standar Deviasi $=0,569$ & & \\
\hline
\end{tabular}

\section{Kompensasi Nonfinansial (X2)}

Variabel kompensasi nonfinansial terdiri dari dua dimensi yaitu dimensi pekerjaan dan lingkungan pekerjaan. Dimensi pekerjaan dengan indikator yaitu tugas-tugas yang menarik, tantangantantangan, tanggung jawab, pengakuan dan rasa pencapaian terdiri dari 6 item pernyataan. Dimensi lingkungan pekerjaan dengan indikator yaitu kebijakan- 
kebijakan yang sehat, supervisi yang kompeten dan kerabat kerja yang menyenangkan terdiri dari 6 item pernyataan, dengan demikian ada 12 item pernyataan untuk variabel kompensasi nonfinansial (X2).

Tabel

Statistik Deskriptif Variabel Kompensasi Nonfinansial

\begin{tabular}{|l|r|r|}
\hline \multicolumn{1}{|c|}{ Skala } & Frekuensi & \multicolumn{1}{c|}{ Persentase } \\
\hline 1 = Sangat Tidak Setuju & 1 & $0,19 \%$ \\
2 = Tidak Setuju & 2 & $0,38 \%$ \\
3 = Ragu-ragu & 27 & $5,11 \%$ \\
4 = Setuju & 371 & $70,27 \%$ \\
5 = Sangat Setuju & 127 & $24,05 \%$ \\
\hline Total & 528 & $100 \%$ \\
\hline Rata-rata $=4,25$ & & \\
Standar Deviasi $=0,438$ & \\
\hline
\end{tabular}

\section{Kinerja Karyawan (Y)}

Variabel kinerja karyawan terdiri dari tiga dimensi yaitu kriteria berdasarkan pekerjaan, kriteria berdasarkan perilaku, dan kriteria berdasarkan hasil. Dimensi kriteria berdasarkan sifat, dengan indikator yaitu kemampuan, loyalitas, transparansi, kreatifitas dan kemampuan memimpin terdiri dari 14 item pernyataan.

Dimensi kriteria berdasarkan perilaku, dengan indikator yaitu melaksanakan tugas, mengikuti instruksi, melaporkan permasalahan, memelihara peralatan, mengikuti aturan-aturan dan mengajukan usul terdiri dari 12 item pernyataan. Dimensi kriteria berdasarkan hasil, dengan indikator yaitu hasil yang dicapai sesuai dengan perencanaan, kualitas pekerjaan, pekerjaan yang tersisa dan kemampuan memperbaiki peralatan terdiri dari 4 item pernyataan, dengan demikian ada 30 item pernyataan untuk variabel kinerja karyawan (Y).

Tabel

Statistik Deskriptif Variabel Kinerja Karyawan

\begin{tabular}{|l|r|r|}
\hline \multicolumn{1}{|c|}{ Skala } & Frekuensi & \multicolumn{2}{c|}{ Persentase } \\
\hline 1= Sangat Tidak Setuju & - & $0,9 \%$ \\
2= Tidak Setuju & 12 & $2,96 \%$ \\
3 = Ragu-Ragu & 39 & $64,47 \%$ \\
4 = Setuju & 851 & $31,67 \%$ \\
5 = Sangat Setuju & 418 & $100 \%$ \\
\hline Total & 1320 & \\
\hline Rata-rata =4,20 & & \\
Standar deviasi $=0,462$ & & \\
\hline
\end{tabular}

\section{Uji Validitas Data}

Pengujian validitas data dalam penelitian ini menggunakan metode korelasi Bivariate Pearson (Korelasi Pearson Product Moment). Priyatno (2010:90)
Pengujian menggunakan uji dua sisi dengan taraf signifikansi 0,05 . Kriteria pengujian kriteria pengujiannya adalah jika $r$ hitung $\geq r$ tabel maka instrumen atau item-item pernyataan berkorelasi signifikan terhadap skor total (dinyatakan valid). Jumlah data $(n)=44$, maka didapat 
r tabel sebesar 0,297. Setelah dilakukan pengujian validitas data pada variabel kompensasi finansial semua item pernyataan dinyatakan valid, begitu pula pada variabel kompensasi nonfinansial semua item pernyataan juga dinyatakan valid. Sedangkan pada variabel kinerja karyawan diketahui ada 1 item pernyataan yang tidak valid yaitu item pernyataan 30 . Oleh karena itu, 1 item tersebut tidak disertakan dalam pengujian tahap selanjutnya.

Hasil uji validitas untuk masingmasing variabel penelitian dapat dilihat pada tabel 5.6, tabel 5.7 dan tabel 5.8

Tabel

Hasil Uji Validitas Variabel Kompensasi Finansial

\begin{tabular}{|c|c|c|c|}
\hline Item / pernyataan ke & r hitung & r tabel & Keterangan \\
\hline 1 & 0,647 & 0,297 & Valid \\
\hline 2 & 0,720 & 0,297 & Valid \\
\hline 3 & 0,829 & 0,297 & Valid \\
\hline 4 & 0,607 & 0,297 & Valid \\
\hline 5 & 0,741 & 0,297 & Valid \\
\hline 6 & 0,803 & 0,297 & Valid \\
\hline 7 & 0,740 & 0,297 & Valid \\
\hline 8 & 0,701 & 0,297 & Valid \\
\hline 9 & 0,824 & 0,297 & Valid \\
\hline 10 & 0,759 & 0,297 & Valid \\
\hline 11 & 0,824 & 0,297 & Valid \\
\hline 12 & 0,803 & 0,297 & Valid \\
\hline
\end{tabular}

Tabel

Hasil Uji Validitas Variabel Kompensasi Nonfinansial

\begin{tabular}{|c|c|c|c|}
\hline Item / pernyataan ke & r hitung & r tabel & Keterangan \\
\hline 1 & 0,613 & 0,297 & Valid \\
\hline 2 & 0,545 & 0,297 & Valid \\
\hline 3 & 0,552 & 0,297 & Valid \\
\hline 4 & 0,577 & 0,297 & Valid \\
\hline 5 & 0,748 & 0,297 & Valid \\
\hline 6 & 0,527 & 0,297 & Valid \\
\hline 7 & 0,674 & 0,297 & Valid \\
\hline 8 & 0,724 & 0,297 & Valid \\
\hline 9 & 0,844 & 0,297 & Valid \\
\hline 10 & 0,92 & 0,297 & Valid \\
\hline 11 & 0,675 & 0,297 & Valid \\
\hline 12 & 0,566 & 0,297 & Valid \\
\hline
\end{tabular}

Tabel

Hasil Uji Validitas Variabel Kinerja Karyawan

\begin{tabular}{|l|c|c|c} 
Item / pernyataan ke & r hitung & $\mathbf{r}$ tabel & Keterangan
\end{tabular}




\begin{tabular}{|c|c|c|c|}
\hline 1 & 0,521 & 0,297 & Valid \\
\hline 2 & 0,416 & 0,297 & Valid \\
\hline 3 & 0,433 & 0,297 & Valid \\
\hline 4 & 0,697 & 0,297 & Valid \\
\hline 5 & 0,590 & 0,297 & Valid \\
\hline 6 & 0,666 & 0,297 & Valid \\
\hline 7 & 0,443 & 0,297 & Valid \\
\hline 8 & 0,693 & 0,297 & Valid \\
\hline 9 & 0,699 & 0,297 & Valid \\
\hline 10 & 0,711 & 0,297 & Valid \\
\hline 11 & 0,495 & 0,297 & Valid \\
\hline 12 & 0,679 & 0,297 & Valid \\
\hline 13 & 0,674 & 0,297 & Valid \\
\hline 14 & 0,634 & 0,297 & Valid \\
\hline 15 & 0,449 & 0,297 & Valid \\
\hline 16 & 0,717 & 0,297 & Valid \\
\hline 17 & 0,572 & 0,297 & Valid \\
\hline 18 & 0,699 & 0,297 & Valid \\
\hline 19 & 0,431 & 0,297 & Valid \\
\hline 20 & 0,620 & 0,297 & Valid \\
\hline 21 & 0,623 & 0,297 & Valid \\
\hline 22 & 0,643 & 0,297 & Valid \\
\hline 23 & 0,675 & 0,297 & Valid \\
\hline 24 & 0,693 & 0,297 & Valid \\
\hline 25 & 0,677 & 0,297 & Valid \\
\hline 26 & 0,607 & 0,297 & Valid \\
\hline 27 & 0,667 & 0,297 & Valid \\
\hline 28 & 0,489 & 0,297 & Valid \\
\hline 29 & 0,392 & 0,297 & Valid \\
\hline 30 & 0,260 & 0,297 & Tidak Valid \\
\hline
\end{tabular}

\section{Uji Reliabilitas Data}

Uji reliabilitas data dalam penelitian ini menggunakan metode
Cronbanch's Alpha. Hasil uji reliabilitas dapat dilihat pada tabel 5.9.

Tabel 5.9

Hasil Uji Reliabilitas

\begin{tabular}{|c|c|c|}
\hline Variabel & Cronbanch's Alpha & Keterangan \\
\hline Kompensasi Finansial & 0,927 & Reliabel \\
\hline Kompensasi Nonfinansial & 0,864 & Reliabel \\
\hline Kinerja Karyawan & 0,934 & Reliabel \\
\hline
\end{tabular}

\section{Uji Normalitas}

Untuk mendeteksi normalitas data dapat dilihat melalui output grafik kurva normal p-plot. Suatu variabel dikatakan normal jika gambar distribusi dengan titiktitik data yang menyebar di sekitar garis diagonal dan penyebaran titik-titik data searah mengikuti garis diagonal. 
Gambar

Grfik $p$-plot

Scatterplot

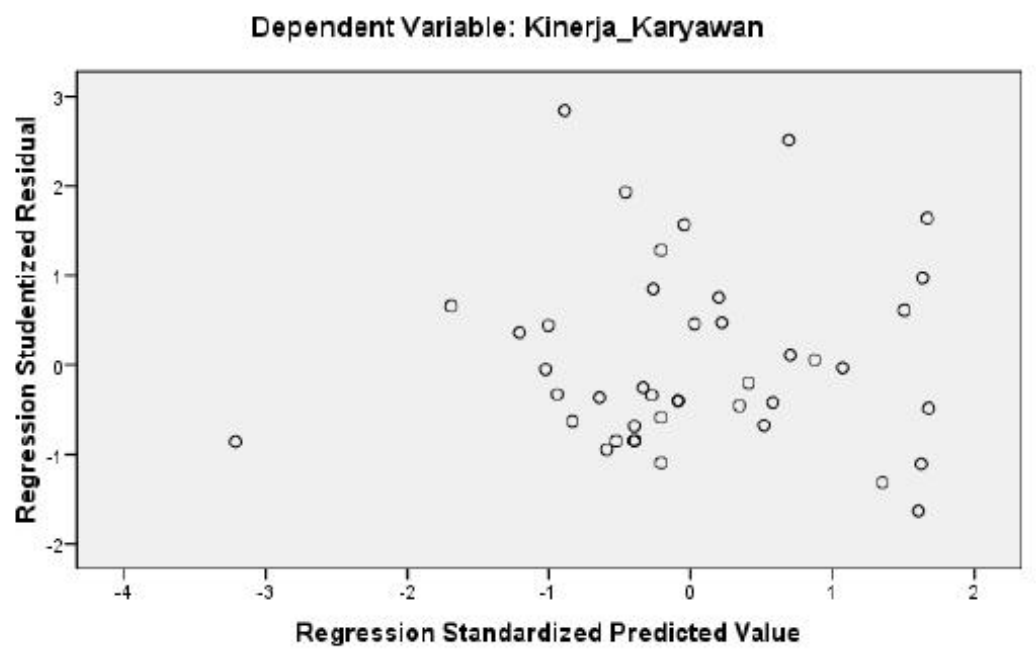

Uji Multikolinearitas

Peneliti melakukan uji

multikolinearitas dengan melihat nilai Inflation Factor (VIF) pada model regresi. Hasil uji multikolinearitas dapat dilihat pada tabel 5.10. Pada tabel tersebut dapat dilihat nilai VIF untuk variabel kompensasi finansial adalah sebesar 1,200. Untuk variabel kompensasi nonfinansial, nilai VIF adalah sebesar 1,200 . Nilai VIF untuk variabel kompensasi finansial dan nonfinansial lebih kecil dari 5, maka data penelitian ini bebas dari asumsi multikolinearitas.

Tabel

Hasil Uji Multikolinearitas

\begin{tabular}{|c|c|c|}
\hline \multicolumn{3}{|c|}{ Collinearity Statistics } \\
\hline Variabel & Tolerance & VIF \\
\hline Kompensasi finansial & 0,834 & 1,200 \\
\hline Kompensasi nonfinansial & 0,834 & 1,200 \\
\hline
\end{tabular}

\section{Uji Heteroskedastisitas}

Diagnosis

adanya

heteroskedastisitas dapat dideteksi dengan melihat ada tidaknya pola tertentu pada grafik scatterplot. Apabila grafik penyebaran nilai- nilai residual terhadap nilai-nilai prediksi tidak membentuk suatu pola tertentu, seperti meningkat atau menurun, maka tidak terjadi heteroskedastisitas. Gambar 5.2 memperlihatkan pola yang jelas dimana titik-titik menyebar dan titik-titik tersebut tidak membentuk suatu pola tertentu. Oleh karena itu, dapat disimpulkan bahwa tidak terjadi persoalan heteroskedastisitas 


\section{Analisis Regresi}

Dalam menganalisis hubungan kinerja karyawan (Y) dengan kompensasi finansial (X1) dan kompensasi nonfinansial (X2), digunakan analisis regresi linier berganda.

\section{Analisis Regresi Linier Berganda Hipot esis 1, 2 dan 3}

Berdasarkan tabel 5.12 dapat dibuat persamaan regresi linier berganda sebagai berikut: $\mathrm{Y}=35,824+0,482 \mathrm{X} 1+$ $1,377 \mathrm{X} 2$

Persamaan regresi di atas dapat dijelaskan sebagai berikut :

a. Konstanta sebesar 35,824 artinya jika kompensasi finansial (X1) dan kompensasi nonfinansial (X2) adalah 0 , maka kinerja karyawan (Y) nilainya adalah 35,824 .

b. Koefisien regresi variabel kompensasi finansial (X1) sebesar 0,482, artinya jika kompensasi finansial mengalami kenaikan $1 \%$, maka kinerja karyawan $(\mathrm{Y})$ akan mengalami peningkatan sebesar 0,482 .

c. Koefisien regresi variabel kompensasi nonfinansial (X2) sebesar 1,377, artinya jika kompensasi nonfinansial mengalami kenaikan $1 \%$ maka kinerja karyawan (Y) akan mengalami peningkatan sebesar 1,377 .

Hasil analisis korelasi ganda dalam penelitian ini diperolah angka $\mathrm{R}$ sebesar
0,791, maka dapat disimpulkan bahwa terjadi hubungan yang kuat antara kompensasi finansial dan nonfinansial terhadap kinerja karyawan.

Hasil analisis korelasi ganda (R) dapat dilihat pada tabel 5.12. Analisis determinasi (R2) digunakan untuk mengetahui persentase sumbangan pengaruh variabel independen $(\mathrm{X} 1, \mathrm{X} 2)$ secara serentak terhadap variabel dependen (Y). R2 sama dengan 0, maka tidak ada sedikit pun persentase sumbangan pengaruh yang diberikan variabel independen terhadap variabel dependen, sebaliknya R2 sama dengan 1, maka persentase sumbangan pengaruh yang diberikan variabel independen terhadap variabel dependen adalah sempurna. Hasil analisis determinasi diperoleh angka R2 ( $\mathrm{R}$ Square) sebesar 0,626 atau $(62,6 \%)$. Hal ini menunjukkan bahwa persentase sumbangan pengaruh variabel independen (kompensasi finansial dan kompensasi nonfinansial) terhadap variabel dependen (kinerja karyawan) sebesar $62,6 \%$ atau variasi variabel independen yang digunakan dalam model (kompensasi finansial dan kompensasi nonfinansial) mampu menjelaskan 62,6\% variabel dependen (kinerja karyawan), sedangkan sisanya sebesar 37,4\% dipengaruhi atau dijelaskan oleh variabel lain yang tidak dimasukkan dalam model penelitian ini. Hasil analisis determinasi (R2) dapat dilihat pada tabel 5.12

Tabel

Hasil Analisis Korelasi Ganda (R) dan Korelasi Determinan (R2) Model Summary

\begin{tabular}{|c|c|c|c|c|}
\hline Model & $\mathbf{R}$ & R Square & $\begin{array}{c}\text { Adjusted R } \\
\text { Square }\end{array}$ & $\begin{array}{c}\text { Std. Error of } \\
\text { The Estimate }\end{array}$ \\
\hline 1 & $0,791^{\mathrm{a}}$ & 0,626 & 0,607 & 6,008 \\
\hline
\end{tabular}

Uji Hipotesis Pengaruh Kompensasi Finansial terhadap Kinerja Karyawan 
Tabel

Uji T Hipotesis Pertama

Coefficients ${ }^{a}$

\begin{tabular}{|c|c|c|c|c|c|}
\hline \multirow[b]{2}{*}{ Model } & \multicolumn{2}{|c|}{$\begin{array}{c}\text { Unstandardized } \\
\text { Coefficients }\end{array}$} & \multirow{2}{*}{$\begin{array}{c}\begin{array}{c}\text { Standardized } \\
\text { Coefficients }\end{array} \\
\text { Beta }\end{array}$} & \multirow[b]{2}{*}{$\mathrm{t}$} & \multirow[b]{2}{*}{ Sig. } \\
\hline & $\mathbf{B}$ & Std. Errol & & & \\
\hline 1 (Constant) & 35,824 & 11,431 & & 3,134 & 0,003 \\
\hline Kompensasi Finansial & 0,482 & 0,149 & 0,339 & 3,240 & 0,002 \\
\hline Kompensasi Nonfinansial & 1,377 & 0,244 & 0,590 & 5,632 & 0,000 \\
\hline
\end{tabular}

a. Dependent Variable: Kinerja Karyawan

Uji Hipotesis Pengaruh Kompensasi Nonfinansial terhadap Kinerja Karyawan

Tabel

Hasil Uji T Hipotesis Kedua

Coefficients $^{a}$

\begin{tabular}{|c|c|c|c|c|c|}
\hline \multirow[b]{2}{*}{ Model } & \multicolumn{2}{|c|}{$\begin{array}{c}\text { Unstandardized } \\
\text { Coefficients }\end{array}$} & \multirow{2}{*}{$\begin{array}{c}\begin{array}{c}\text { Standardized } \\
\text { Coefficients }\end{array} \\
\text { Beta } \\
\end{array}$} & \multirow[b]{2}{*}{$\boldsymbol{t}$} & \multirow[b]{2}{*}{ Sig. } \\
\hline & B & Std. Errol & & & \\
\hline 1 (Constant) & 35,824 & 11,431 & & 3,134 & 0,003 \\
\hline Kompensasi Finansial & 0,482 & 0,149 & 0,339 & 3,240 & 0,002 \\
\hline Kompensasi Nonfinansial & 1,377 & 0,244 & 0,590 & 5,632 & 0,000 \\
\hline
\end{tabular}

Uji Hipotesis Pengaruh Kompensasi Finansial dan Nonfinansial terhadap Kinerja Karyawan

Tabel

Hasil Uji F Hipotesis Ketiga

ANOVAb

\begin{tabular}{|c|c|c|c|c|c|}
\hline Model & Sum of Squares & Df & Mean Square & $\mathbf{F}$ & Sig. \\
\hline $1 \quad$ Regression & 2472,872 & 2 & 1236,436 & 34,254 & $0,000^{\mathrm{d}}$ \\
\hline Residual & 1479,924 & 41 & 36,096 & & \\
\hline Total & 3952,795 & 43 & & & \\
\hline
\end{tabular}

a. Predictors : (Constant), Kompensasi Nonfinansial, Kompensasi Finansial

b. Dependent Variable : Kinerja Karyawan

Uji Hipotesis Perbedaan Kinerja antara Karyawan Tetap dan Karyawan Kontrak

Pengujian hipotesis keempat dianalisis dengan menggunakan
Independent Samples $\mathrm{T}$ Test. Hasil Independent Samples T Test dapat dilihat pada tabel 5.16 
Tabel

Hasil Uji Independent Samples T Test Hipotesis Keempat

\begin{tabular}{|l|l|r|r|}
\hline \multicolumn{2}{|c|}{} & \multicolumn{2}{c|}{ Kinerja Karyawan } \\
\cline { 3 - 4 } \multicolumn{2}{|c|}{} & $\begin{array}{c}\text { Equal } \\
\text { Variances } \\
\text { Assumed }\end{array}$ & $\begin{array}{c}\text { Equal } \\
\text { Variances Not } \\
\text { Assumed }\end{array}$ \\
\hline $\begin{array}{l}\text { Levene } \\
\text { Equality Test For }\end{array}$ & F & 1,908 & \\
$\begin{array}{l}\text { Variances } \\
\text { t-test for Quality } \\
\text { of Means }\end{array}$ & Sig. & 0,174 & \\
& t & 0,068 & 0,075 \\
& df & 42 & 41,017 \\
& Sig.(2-tailed) & 0,946 & 0,940 \\
& Mean difference & 0,205 & 0,205 \\
& Std.error difference & 3,040 & 2,722 \\
& 95\% confidence & & \\
& interval of differences & & $-5,292$ \\
& Lower & $-5,930$ & 5,702 \\
\hline
\end{tabular}

\section{KESIMPULAN}

Penelitian ini bertujuan untuk mengetahui pengaruh kompensasi finansial dan nonfinansial terhadap kinerja karyawan serta untuk mengetahui perbedaan kinerja antara karyawan tetap dan karyawan kontrak PT. Bank Rakyat Indonesia (Persero) Tbk. Cabang Teluk Kuantan. Berdasarkan analisis data dan pembahasan yang telah dilakukan, maka dapat ditarik kesimpulan sebagai berikut:

1. Kompensasi finansial berpengaruh positif dan signifikan terhadap kinerja karyawan. Hal ini dapat dilihat dari nilai $t$ hitung $>t$ tabel $(3,240>2,020)$ dan nilai signifikansi $<$ taraf signifikansi $(\alpha) 0,05(0,002<0,05)$.

2. Kompensasi nonfinansial berpengaruh positif dan signifikan terhadap kinerja karyawan. Hal ini dapat dilihat dari nilai $\mathrm{t}$ hitung $>\mathrm{t}$ tabel $(5,632>2,020)$ dan nilai signifikansi $<$ taraf signifikansi $(\alpha) 0,05(0,000<0,05)$.

3. Kompensasi finansial dan kompensasi nonfinansial secara simultan berpengaruh positif dan signifikan terhadap kinerja karyawan. Hal ini dapat dilihat dari nilai $\mathrm{F}$ hitung $>\mathrm{F}$ tabel $(34,254>3,226)$ dan nilai signifikansi $<$ taraf signifikansi $(\alpha)$ $0,05(0,000<0,05)$.

4. Tidak terdapat perbedan kinerja antara karyawan tetap dan karyawan kontrak. Hal ini dapat dilihat dari nilai $\mathrm{t}$ hitung $<\mathrm{t}$ tabel $(0,068<2,018)$ dan nilai signifikansi > taraf signifikansi (a) $0,05(0,946>0,05)$ melalui uji Independent Samples T Test

\section{Keterbatasan}

Keterbatasan-keterbatasan dalam penelitian ini adalah sebagai berikut :

1. Sampel yang digunakan dalam penelitian ini hanya berasal dari perusahaan publik yang bergerak di bidang jasa perbankan (PT. Bank Rakyat Indonesia (Persero) Tbk. Cabang Teluk Kuantan), sehingga tidak menutup kemungkinan akan diperoleh hasil yang berbeda jika menggunakan sampel dari perusahaan dagang dan manufaktur.

2. Data yang dianalisis menggunakan instrumen yang berdasarkan persepsi 
jawaban responden, sehingga hal ini akan menimbulkan masalah bila persepsi jawaban responden berbeda

\section{Saran} dengan keadaan yang sesungguhnya.

Saran dari peneliti adalah sebagai berikut :

1. PT. Bank Rakyat Indonesia (Persero) Tbk. Cabang Teluk Kuantan sebaiknya mempertahankan dan meningkatkan kompensasi finansial dan nonfinansialnya, karena kedua variabel ini dapat meningkatkan kinerja karyawannya.

2. Penelitian selanjutnya hendaknya memperluas sampel penelitian, tidak hanya pada karyawan PT. Bank Rakyat Indonesia (Persero) Tbk. Cabang Teluk Kuantan saja, tetapi dapat mengambil sampel dari perusahaan dagang dan manufaktur, sehingga hasil penelitiannya dapat lebih tergeneralisasi.

\section{DAFTAR PUSTAKA}

Allo, Elisa Bunga. 2002. Analisis Kompensasi terhadap Kinerja Pegawai Dinas Perhubungan Kabupaten Donggala. Tesis. Teluk Kuantan. Program Pascasarjana Universitas Hasanuddin.

Anthony, Robert N dan Vijay Govindarajan. 2005. Sistem Pengendalian Manajemen. Buku Dua. Jakarta : Salemba Empat.

Arep, Ishak dan Hendri Tanjung. 2003. Manajemen Motivasi. Jakarta : PT. Gramedia Widiasarana Indonesia.

Hasibuan, Malayu S.P. 2008. Manajemen Sumber Daya Manusia. Edisi Revisi. Jakarta : PT. Bumi Aksara.

Mangkunegara, A. A. Anwar Prabu. 2004. Manajemen Sumber Daya Manusia Perusahaan. Cetakan Kelima. Bandung : PT. Remaja
Rosdakarya.

Martoyo, Susilo. 2007. Manajemen Sumber Daya Manusia. Edisi Kelima. Yogyakarta : PT. BPFE.

Mondy, R. Wayne, Robert M. Noe and Shane R. Premeaux. 1993. Human Resource Management. Fifth Edition. Massachusetts : Allyn and Bacon.

Mulyadi. 2004. Akuntansi Manajemen : Konsep, Manfaat, dan Rekayasa. Edisi Ketiga. Cetakan Ketiga. Jakarta : Salemba Empat.

Nawawi, Hadari. 2005. Manajemen Sumber Daya Manusia : untuk Bisnis yang Kompetitif. Yogyakarta : Gadjah Mada University Press.

Panggabean, Mutiara S. 2004. Manajemen Sumber Daya Manusia. Cetakan Kedua. Bogor Selatan : Ghalia Indonesia.

Priyatno, Duwi. 2010. Paham Analisa Statistik Data dengan SPSS. Cetakan Pertama. Yogyakarta : Mediakom.

Rahayu, Diyan Kurniawati. 2008. Pengaruh Sistem Penghargaan terhadap Kinerja Pegawai pada Perum Bulog Divisi Regional Palu. Skripsi S1. Palu : Fakultas Ekonomi Universitas Tadulako

Riduwan. 2011. Belajar Mudah Penelitian untuk Guru-Karyawan dan Peneliti Pemula. Bandung : Alfabeta.

Samsuddin, Sadili. 2006. Manajemen Sumber Daya Manusia. Cetakan Pertama. Bandung : Pustaka Setia.

Sastrohadiwiryo, B. Siswanto. 2005. Manajemen Tenaga Kerja Indonesia Pendekatan Administratif dan Operasional. Cetakan Ketiga. Jakarta : PT. Bumi Aksara.

Sitohang, Andre. Perbedaan Karyawan 
$\begin{array}{lr}\text { Kontrak } & \text { (Outsourcing) } \\ \text { dengan } & \text { Karyawan }\end{array}$

Tetap.http://andresitohang.word press.com/about/perbedaan

karyawan-kontrakoutsourcingdengan-karyawan-tetap/.

Diakses pada tanggal 19 Maret 2012.

Sugiyono. 2012. Metode Penelitian

Kuantitatif Kualitatif dan R\&D.

Bandung : Alfabeta.

Sunyoto, Agus. 1991. Manajemen

Sumber Daya Manusia. Jakarta : STIE IPWI.

Syaifullah. 2005. Organisasi. Org Komunitas \& Perpustakaan Online Indonesia. Pengertian Kompensasi dan Jenis / Macam Kompensasi Sdm - Upah, Gaji, Insentif, Tunjangan, dsb. http://pengertian-kompensasijenis-macam-kompensasi-sdmupah-gaji-insentif-tunjangandsb.htm.Diakses pada tanggal 17 November 2011.

Wikipedia Ensiklopedia Bebas. Bank Rakyat Indonesia.

http://id.wikipedia.org/wiki/Ban k_Rakyat_Indonesia. Diakses pada tanggal 25 Maret 2012 